\title{
The polyfunctional lexeme /fard/ in the Arabic dialects of Iraq and Khuzestan
}

\section{More than an indefinite article}

\author{
Bettina Leitner | ORCID: 0000-0001-6712-302X \\ Department of Near Eastern Studies, University of Vienna, Vienna, Austria \\ bettina.leitner@univie.ac.at \\ Stephan Procházka | ORCID: 0000-0001-9421-1404 \\ Department of Near Eastern Studies, University of Vienna, Vienna, Austria \\ stephan.prochazka@univie.ac.at
}

\begin{abstract}
The primary aim of this paper is to explore the functions of the word /fard/ in Iraqi and Khuzestani Arabic. The study is based on the analysis of various text corpora and the elicitation of further examples from native speakers of the varieties investigated. The analysis of these data has shown that /fard/ is a polyfunctional item. Its various functions are the result of several grammaticalization processes. In the first stage, the noun "individual" has become a quantifier that expresses singularity. From this stage it developed into an intensifier, a marker of approximation and the scalar adverb "only." It has been demonstrated that, from its use as a presentative marker, it developed toward an indefinite article. In contrast to the definite article, which is a grammatical category in nearly every variety of Arabic, the use of an indefinite article is rarely found in spoken Arabic. In Iraqi and Khuzestani Arabic, /fard/ is an indefinite article that possesses a wide range of applications and only a limited set of constraints. Its use, however, remains optional to a very high degree. Its main function is that of a presentativei.e., introducing a new referent into a discourse. In addition, it also functions as an individuation marker, as a marker for expressing the speaker's epistemic status (knowledge/ignorance) regarding a referent, and indicating free choice from a set of potential referents. Related to this last function is its use as a mitigating device in imperatives and polite requests.
\end{abstract}




\section{Keywords}

grammaticalization - indefinite article - quantifiers - Arabic dialectology - Iraqi Arabic - Khuzestani Arabic

Like all other varieties of Arabic (including very early forms of Arabic, see PatEl 2009 and Testen 1998: 155-168), Iraqi and Khuzestani Arabic possess a fully grammaticalized definite article. All grammatical descriptions of these two varieties unanimously report that they also possess an indefinite article. ${ }^{2}$ A look at the World Atlas of Language Structures (WALS) ${ }^{3}$ shows that the existence of such an article is a feature that is rarely found in Arabic. ${ }^{4}$ The indefinite article /wāḩəd-l-/ is used in the varieties spoken in Morocco and west Algeria, and is derived from the numeral "one." On the other edge of the Arabic-speaking world, Iraqi Arabic uses reflexes of the Classical Arabic noun fard 'individual (thing or person)' to mark different kinds of indefiniteness (Jastrow 2007: 419-420). ${ }^{5}$ The same indefinite article is found in other regions that have not been covered by WALS: in the closely related varieties spoken in the Iranian province of Khuzestan, in the Arabic dialects of the Iranian coast of the Gulf (e.g., Bandar Moqam, Hormozgan), ${ }^{6}$ and in all Arabic-speaking Sprachinseln of Central Asia—i.e., Khorasan, Uzbekistan and Afghanistan (Seeger 2013; 2002). Although this paper focuses on the two areas stated in its title, it is worth mentioning that the functions of /fard/ are very similar in all of the regions in which it is attested.

1 We thank the anonymous reviewer for the numerous valuable suggestions, which initiated a reconsideration of and substantial change to our original approach. We are also grateful to Dina El Zarka and Utz Maas (University of Graz) and Veronika Ritt-Benmimoun (University of Vienna) for their valuable comments on earlier drafts of this paper.

2 For example, Blanc (1964: 118-119); Erwin (1963: 355-358); Ingham (2007: 575); Leitner (2020: 147-149); Malaika (1963: 69).

3 Map no. 38; see http://wals.info/feature/38A\#2/25.5/148.2.

4 For a good overview, see Mion (2009).

5 The existence of an indefinite article can be regarded as one of the few characteristic features that is shared by all layers of Iraqi Arabic - both the archaic qaltu-type dialects spoken in the urban centers of the north (particularly Mosul) and the bedouin-type gilit dialects that preponderate in the countryside and the whole of the south (for details of this diachronic split, cf. Holes 2007).

6 The existence of /fard/ in these varieties was recently "discovered" by the first author of this paper (see Leitner et al. 2021). 
In spite of it being such a prominent feature of Iraqi Arabic, there has never been an in-depth study on the exact functions of /fard/. In particular, the contrast between unmarked nouns and nouns marked by /fard/ has not yet been sufficiently analyzed. It has also been widely neglected that /fard/ has several other functions that are incompatible with the term "indefinite article." Wherever the subject is treated (e.g., Edzard 2006: 189; Mion 2009: 218219), the authors mainly rely on Erwin's Iraqi Grammar (1963: 355-358) and the brief remarks in Blanc's seminal study on Baghdadi Arabic, where it was already noted that the "details of usage are obviously complex" (Blanc 1964: 118-119).

In Iraqi and Khuzestani Arabic, /fard/ is invariable with regard to gender and number and mainly occurs in combination with singular nouns (for other possible combinations, see § 3.3.3). In all varieties, /fard/ immediately precedes the noun it marks, except when the noun is modified by the adjective $x \bar{o}$ ' 'good, nice. ${ }^{7}$ As for its actual phonetic shape, there are only slight differences among the dialects. In the prestigious Muslim dialect of Baghdad, /fard/takes the form of $\mathrm{fadd} \sim \mathrm{fad}$-i.e., with assimilation of the $/ \mathrm{r} /$ to the following /d/. Assimilation of the final $-d$ to a following (palato-)alveolar or dental consonant is also attested, though rare (see § 4.3). Fard farad is most common in southern Iraq and Khuzestan, while fag $\sim$ fagjad, which shows the shift $/ \mathrm{r} />/ \dot{\mathrm{g}} /$ typical of the Tigris branch of the Iraqi qaltu-type dialects, is most frequently found in Mosul.

\subsection{Aims and research questions}

Our primary aim is to describe the functions of /fard/, including those that cannot be subsumed under the term "indefinite article," which /fard/ is usually labelled. For a better understanding of how these different functions have emerged, we will propose different pathways of grammaticalization in section 2. We are aware that grammaticalization is an extremely wide and much discussed topic on which several reference works have been published in just the last few years (cf. the introductory chapter in Narrog and Heine 2018).

The process of grammaticalization of /fard/ has only ever been briefly described, predominantly in works dedicated to Semitic Studies (Rubin 2005:1819) or Arabic Studies (Mion 2009). Many general works on grammaticalization only rudimentarily cover Arabic, and /fard/ as an example of grammaticaliza-

7 E.g., fadd xōš ādmi 'a fine man' (McCarthy and Raffouli 1965: 88/49). The invariable adjective $x \bar{s} s ̌$ is a loan from Persian and, unlike other adjectives, which follow their head noun, is positioned in front of its head. 
tion is thus very rarely treated. It is briefly mentioned in Kuteva et al. (2019: 300 ), but ignored in the general article on grammaticalization in the Semitic languages by Esseesy (2018).

Our article does not examine the question of why the noun fard, and not the numeral "one," has been the source item for the grammaticalization process. Nor does it analyze the role of language contact in the grammaticalization of /fard $/ .8$ Both of these topics will be addressed in a separate article which is in the making.

Our main research questions are:

- What are the different functions of /fard/ and how frequently are these functions attested in our corpora?

- Which different paths and different stages of grammaticalization underlie its polyfunctional and polysemantic nature?

- Is it really appropriate to call /fard/ an "indefinite article"?

- If yes, has it developed into a distinct grammatical category comparable to the definite article?

- Are there particular contexts in which speakers prefer NPs marked by /fard/ over bare nouns?

- Are there limitations and constraints for its use?

\subsection{Data}

In order to answer our research questions, we analyzed the usage of /fard/ in different corpora of Iraqi and Khuzestani Arabic. Only smaller corpora are available for most spoken Arabic varieties, and these are often not up to date. Our selection thus also consists of a rather heterogeneous collection containing data stretching from the early 20 th century to the present. The overall size of the five corpora analyzed is roughly 100,00o words: Mosul 7,600 (mostly descriptions, recipes, narratives); Baghdad 41,200 (dialogues, screenplays, anecdotes, descriptions); Kwayriš/Babylon 15,500 (mainly narratives and anecdotes, a few descriptions); al-Hiilla, al- ${ }^{\mathrm{s}} \mathrm{Afač}$, and al-Bașra 1,60o (stories and narratives); Khuzestan 35,000 (stories, narratives, descriptions, dialogues). ${ }^{9}$

8 Suffice it to say, different kinds of so-called indefinite articles are found in most of the languages Iraqi and Khuzestani Arabic once had or still have contact with, particularly Ottoman Turkish, Iraqi Turkmen, Persian, Kurdish and Neo-Aramaic.

9 The text collections that constitute our five corpora are found in the following publications and field notes: Mosul: Jastrow 1979; 1991; 2004; 2005—Baghdad: McCarthy and Raffouli 1965 (37,000) and the authentic dialogues (4,200) found in Leitner, German, and Procházka 2021Kwayriš (Babylon): Meißner 1903-al-Ḥilla, al-``Afač, al-Bașra: Denz and Edzard 1966Khuzestan: not yet published, this corpus is based on fieldwork data and was compiled by the first author of this paper in Khuzestan in 2016 and in Kuwait in 2018. 
The analysis of the texts was supplemented by data elicited from native speakers of both regions. ${ }^{10}$

\section{Grammaticalization chains and the functions of /fard/}

Grammaticalization is primarily seen as a diachronic development (Kuteva et al. 2019:12; Hopper and Traugott 2003:2). Therefore, we will attempt to propose reasonable diachronic developments from a lexical item to a grammatical item that becomes more grammatical (López-Couso and Seoane 2017: 277). However, with the caveat that, in spite of the long history of Arabic, the different stages of grammaticalization cannot be proven with text evidence, as there are virtually no sources of spoken Iraqi and Khuzestani Arabic before the early zoth century. Hence, Old and Classical Arabic remain, to a large extent, the only points of reference when trying to reconstruct diachronic developments. For that reason, the grammaticalization pathways presented in the following sections are much more hypothetical ${ }^{11}$ than, for instance, the reconstruction of the development of the indefinite articles in Germanic and Romance languages, where ample data is available for all historical stages (see, e.g., Presslich 2000).

In order to explain the mechanisms which underlie the different grammaticalization chains, we will apply — wherever reasonable — three principles that affect the functional changes that are characteristic of certain subprocesses of grammaticalization: these are (1) subjectification, (2) intersubjectification and (3) objectification. The first two principles were mainly elaborated by E.C. Traugott (e.g., Traugott 1995, 2003, 2012). Subjectification has been defined as "the development of grammatically identifiable expressions of speaker belief or

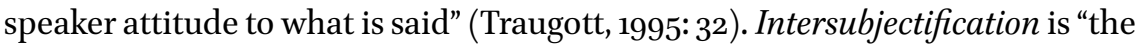
semasiological process whereby meanings come over time to encode or externalize implicatures regarding SP[eaker]'s attention to the 'self' of $\mathrm{AD}$ [resse]s in both an epistemic and a social sense" (Traugott 2003: 129-130). Objectification (or desubjectification) "includes semantic widening from a more restricted, pragmatically motivated use to a general use as default marker of [the] grammatical categories" (Breban 2015: 168, Kranich 2008).

10 We are particularly grateful to Majed Naseri from Ahwaz, Fady German from Baghdad, Akhlas and Dorgham Abudi from Kirkuk, and Dr. Qasim Hassan from Nasiriyya, who patiently answered our questions and were willing to produce a large number of examples (and counter-examples).

11 Cf. the similar remarks with regard to the development of aspect systems in spoken Arabic dialects in (Hanitsch 2019: 583-585). 


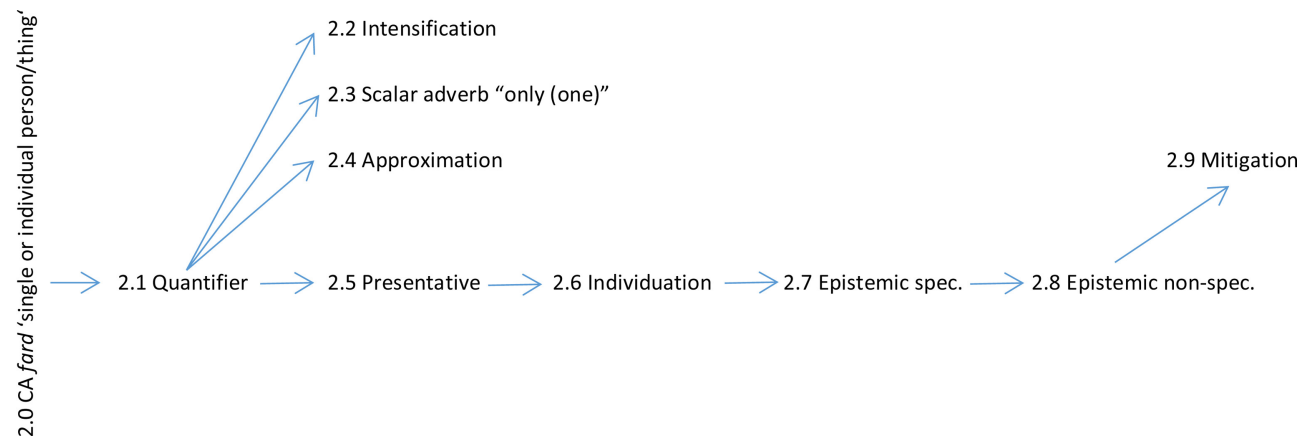

FIGURE 1 Possible grammaticalization scales of /fard/

In this section (2.0-2.9) we discuss the main functions of /fard/ and provide typical examples within their contexts. The section is structured according to possible grammaticalization pathways that include several forks. Figure 1 illustrates these pathways in a sketch diagram.

\subsection{The source item fard 'single or individual (person/thing)'}

There can be no doubt that the source or content item from which the grammaticalization process started is the noun fard. It is well attested in Classical Arabic in the meaning of 'single or individual (person/thing)'. In Classical Arabic, it is inflected according to gender (F fard-a) and number ( $\mathrm{PL}^{2}$ afräd, rarely furāa $\bar{a}$ ), and also used in the sense 'one (of a pair)'. As an adjective, it means 'single, sole, solitary' and follows the noun it qualifies—e.g., tawr-un fard-un 'a bull that is apart from others'. In this meaning, fard is restricted to MSG.; when agreement with $\mathrm{F}$ nouns is required, forms derived from the same root (particularly färid-at-un) are used (Lane 1863:2363-2364). The word fard occurs several times in the Koran-e.g., Sūra 19:95: kull-u-hum 'āti-hiyawm-a l-qiyāmat-ifardan 'Every one of them shall come to Him upon the Day of Resurrection, all alone.' (Translation by Arberry)

As will be shown in the following sections, similar grammaticalization pathways are cross-linguistically widely attested, though with the difference that, in most other languages, the numeral "one" is the source item. ${ }^{12}$ We will not explicitly refer to this fact in each instance.

12 Cf. Kuteva et al. (2019: 299-301), and (especially for the indefinite articles) De Mulder and Carlier (2011: 520). 


\section{1 'Individual' $\rightarrow$ quantifier 'one single' $=$ expression of singularity}

The first phase of grammaticalization is from a full-fledged noun to a quantifier meaning 'one single'. This is the only stage for which we possess diachronic evidence, as this use of /fard/ is already attested in 14th century Iraqi vernacular poetry (Levin 1975: 271). In this function, the semantic range of /fard/ is restricted to cases in which the singularity of an item is emphasized. /fard/ precedes the noun and is invariable in gender. Such a morpho-syntactical change (also called "decategorization") is typical for grammaticalization processes (see López-Couso and Seoane 2017: 280). Syntactically, NPs expressing singularity are no different from those described in the sections below. However, there is a clear tendency toward a prosodic difference, as in this function /fard/ attracts the stress peak of the whole phrase ${ }^{13}$ (indicated by $\langle "\rangle$ in examples from our own data for which we possess audio recordings), as in (1), in which the speaker emphasizes that his father and his uncle are still living in the same house and have not moved to different places after their marriages.

(1) Khuzestan (corpus Leitner)

${ }^{2} u b \bar{u}-y \quad w \quad{ }^{\varsigma} a m m-i$ mu $m^{\varsigma} \bar{a} z l-\bar{i}$ "farad bèt father-1SG and uncle-1SG NEG separated.AP-MPL ONE.SINGLE house $m \bar{a}$ 'azal-u.

NEG separated-3MPL

'My father and my uncle are not (living) apart, (they live in) one house, they have not separated.'

A frequently used phrase that reflects this function is Khuzestani farad sikil 'of one (single) shape $\sim$ totally equal'. /fard/ that expresses singularity can be used emphatically in negated utterances, sometimes reinforced in combination with the focus particle hatta 'even.' This is remarkable because, in most of its other functions, the use of /fard/ in negation is highly restricted (see $\S 3$ ). In (2), the narrator marks qiriš 'piaster' with /fard/, as he wants to emphasize that the protagonist of his story does not even have enough money to buy the most basic food.

13 An exception to this is, for instance, the proverb gawwādēn f-fadd bálad ma yșīr 'You can't have two pimps in one town.' (Blanc 1964: 119). 
(2) Kwayriš (Meißner 1903: 89/13) ${ }^{14}$

$w \quad m \bar{a}$ sand-hum farad qiriš yi-štar-ūn bi-h

and NEG at-3MPL ONE.SINGLE piaster 3 -buy-MPL with-3MSG

xubaz

bread

'And he did not have (even) one single piaster to buy bread.'

In this function, /fard/ competes with the numeral / wāhid/ 'one,' but the latter syntactically behaves like an adjective-i.e., it follows its head noun and agrees with it in gender; e.g., Baghdad: ğigāra wih̆da 'one (single) cigarette' (Erwin 1963: $258)$.

\subsection{Individual' $\rightarrow$ 'one single' $\rightarrow$ 'a (real)' $=$ intensifier}

A function closely related to the preceding is that of an emphasizer or intensifier. As suggested by Traugott (2012: 559-56o), we believe that the function of / fard/ as an intensifier is an example in which subjectification is a factor in the grammaticalization process. The development from 'one single' to 'a real' is similar to the development of adjectives into intensifiers (e.g., English pure, pretty). In both cases, / fard/ expresses the speaker's subjective evaluation of the 'unique' and thus outstanding nature of the person, thing or action denoted by the noun or the adjective marked by it. Therefore, we assume that this function has emerged in a direct step from the meaning 'one single' via subjectification. In (3), the speaker uses / fard/ in combination with a paronomastic object to indicate that the poor boy got a sound beating.

(3) Khuzestan (corpus Leitner)

umm-a katl-att-a farad katla!

mother-3MSG hit-3FSG-3MSG INTENSIFIER stroke

'His mother slapped him hard.'

With 1st person subjects, such usage is interpreted as boasting when positive (4),

(4) Kirkuk (elicited)

'āni fadd fitar maḍ būt

1SG INTENSIFIER fitter skilled

'I am a really skilled fitter.'

14 Here and in the following examples, the German original was translated into English by 
but as modesty when negative, as in (5):

(5) Baghdad (McCarthy and Raffouly 1965:136)

'āni walaw fadd riğğăl faqìr lākin rah-ā-xud-hum

1SG even though INTENSIFIER man poor but FUT-1SG-take-3PL

w-a-rabbi-hum sind-i b-il-bēt

and-1SG-raise -3PL at-1SG in-DEF-house

'I am just a poor man, but I will take them and raise them in my house.'

NPs with the head $n \bar{o} b / n \bar{o} b a$ 'turn, time instance' have become intensifying adverbs like Baghdadi fadd nōba 'too much, to excess' (Woodhead and Beene 1967: 473) and Khuzestani farad nōb 'totally':

(6) Khuzestan (elicited)

àne l-yōm marịda farad nōb

ISG today sick INTENSIFIER time

'Today I am totally sick!'

When /fard/in its intensifying function marks an adjective that is in the syntactic position of a nominal predicate, the adjective is stressed and lengthened. It usually has a special intonation contour, with a higher pitch toward the end of the word. In (7), / fard/ is used to intensify the positive quality of the argument to which the predicate refers, in (8) to express the lacking mental capacity of the boy.

(7) Khuzestan (elicited)

umm-i tubx-at akl-a čān-at farad "halw-aaaa! mother-1SG cooked-3FSG food-F was-3FSG INTENSIFIER delicious-F 'My mother cooked a meal that was really delicious!'

(8) Baghdad (elicited)

fadd "'gabiiii ha-l-walad!

INTENSIFIER silly this-DEF-boy

'This boy is a real dope!'

the authors. The different transcription systems used in the sources have been unified and slightly modified wherever misinterpretations were excluded. 


\subsection{Individual' $\rightarrow$ 'one single' $\rightarrow$ 'only' $=$ restrictive scalar adverb}

The development from 'one' to 'only' is a relatively widespread phenomenon (Kuteva et al. 2019: 302) - e.g., English only (which goes back to an-lic-e 'onelike, uniquely'), and Bulgarian edinstveno (edin 'one' + ADJ-suffix). ${ }^{15}$ Traugott (2003: 127) sees this development as a good example of increased subjectification. This meaning most likely developed from sentences like (9) in which the elderly speaker talks about his school days that were characterized by a shortage of school supplies.

(9) Khuzestan (corpus Leitner)

'ad-na "farad galam $w$ daftar nə-ktab bí

at-1PL ONLY.ONE pen and notebook 1PL-write with.3MSG

'We had only one pen and one notebook to write with.'

The next stage is reached in (10), which is uttered in a context in which the narrator talks about a man who has removed most of his garments. In this example, the meaning "only one" does not make sense, as wearing one shirt and one pair of pants is the common way to dress.

(10) Kwayriš (Meißner 19o3: 18/2)

wa-bāqi 'sale-h farad tōōb wa-libās

and-remain.AP on-3MSG ONLY shirt and-pants

'... and only a shirt and pants remained on him.' $\rightarrow$ 'He wore only a shirt and pants.'

It is worth mentioning that, in this particular function, / fard/ is not restricted to only mark nouns, but may also refer to other parts of speech, including verbse.g., (11) and (12),

(11) Khuzestan (elicited)

šaf-at-l-i (farad) rayyāl čān farad $y$-čadd

saw-1SG-for-1SG INDEF man was.3MSG ONLY 3MSG-lie

'I saw a man-he was only lying!'

15 This meaning is also comparable to English simply, the etymology of which is even closer to $/$ fard/. 
(12) Baghdad (Woodhead and Beene 1967: 347)

čān fadd yi-rìd yi-txallaṣ minn-ak

was.3MSG ONLY 3MSG-want 3MSG-get.rid from-2MSG

'He only wanted to get rid of you.'

and — very rarely — personal pronouns, as in (13).

(13) Baghdad (McCarthy and Raffouly 1965: 39/52) $)^{16}$

ma fadd ğābi rād salay-hum bițāqa fadd

NEG INTENSIFIER conductor wanted.3MSG upon-3PL ticket ONLY inta!

you.MSG

'Not a single conductor wanted a ticket for them (viz. children), only you!'

\section{4 'Individual' $\rightarrow$ 'one single' $\rightarrow$ 'some, about' $=$ approximation and vagueness}

A feature frequently found in our texts is the combination of /fard/ with numerals and expressions of time. In these cases, /fard/ expresses an approximate numerical quantity and is thus another example of subjectification. Cross-linguistically seen, the grammaticalization of the numeral "one" toward a marker of numerical approximation is a widespread phenomenon. Apart from the languages mentioned in Kuteva et al. (2019:304-305), the same grammaticalization path is attested in the Balkan Slavic languages ${ }^{17}$ and in most languages spoken in the Middle East, specifically Turkish, Neo-Aramaic and Persian..$^{18}$ Therefore, the occurrence of this function in Iraqi and Khuzestani Arabic may well be regarded a contact-induced feature. Language contact is also presumed to be responsible for the spread of this feature in the languages of western and central Europe (Heine and Kuteva 2007: 119-133). In Iraqi and Khuzestani Arabic, it likely evolved from usages as in (14), in which the SG noun is marked by /fard/ and followed by a noun in the DUAL. In this example, the speaker describes how the local soup called ḩəssu is made.

16 This usage seems to have become obsolete in contemporary Baghdadi Arabic. All of our informants agreed that it sounds somehow strange and that they would not say it themselves.

17 See Belaj and Matovac (2015) for Croatian, Bulgarian and Macedonian; Breu (2012) for Molise Slavic.

18 Cf. Schroeder (1999: 59) for Turkish; Khan (1999: 200) for Neo-Aramaic. For Persian we elicited data from native speakers. 
(14) Khuzestan (corpus Leitner)

$y$-für farad för-a för-t-ēn $y$-șir

3MSG-boil APPROX boiling-FSG boiling-F-DUAL 3MSG-become

hassu

həossu.soup

'It boils up once or twice and (then) it becomes hassu.'

The form /fard/ can precede phrases consisting of a DUAL noun followed by the numeral "three", as in (15), or two successive numerals larger than "two", as in (16). In these contexts, /fard/ indicates that the number of the following item is between the first and the second or slightly above these values.

(15) Baghdad (McCarthy and Raffouly 1965: 71/5)

ma čān Sind-ič wakit hatta t-rakkb-ìn fadd lōn-ēn

NEG was.3MSG at-2FSG time so.that 2-cook-FSG APPROX kind-DUAL itlāta

three

'You didn't have time to cook two or three kinds (of food).'

(16) Mosul (Jastrow 1979:60/3)

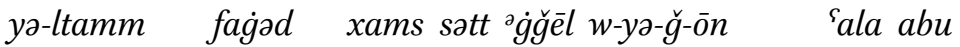
3MSG-gather APPROX five six men and-3-come-PL to father l-banat

DEF-girl

'(Some) five or six men gather and come to the girl's father.'

When a single numeral is modified by /fard/, the speaker wants to indicate that the exact quantity is unknown or unimportant and may be above or below the given number, as in (17).

(17) Khuzestan (corpus Leitner)

$d ə f a^{\varsigma}$-ət farad mīyat yūro l-əl-əktāb-āt

paid-1SG APPROX hundred euro for-DEF-book-PL

'I paid some 100 euros for the books.'

Sometimes /fard/ is found in combination with units of time to indicate approximation, as in (18). 
(18) Kwayriš (Meißner 1903: 24)

xallā-h farad čārak sāa

let.3MSG-3MSG APPROX quarter hour

'He let him (rest) around a quarter of an hour.'

\section{5 'Individual' $\rightarrow$ 'one single' $\rightarrow$ 'a (particular $)$ ' $=$ presentative marker}

From a cross-linguistic perspective, presentative markers are often thought to represent the first stage in the grammaticalization process from the numeral "one" to an indefinite article. Whether or not this also holds true for Iraqi and Khuzestani Arabic is discussed in detail in $\S 4.4$ (to simplify matters here and in $\S 2.6$ to 2.8 , we gloss /fard/ as INDEF).

\subsubsection{Introduction of narratives and anecdotes}

The use of /fard/ as a presentative marker is highly conventionalized at the beginning of fairy tales, traditional narratives and anecdotes (for the numbers, see Table 1 in $\S 4.1$ ). Most often such NPs appear with existentials, particularly čān (aku) 'there was'. In a collection of anecdotes from Baghdad, ${ }^{19}$ 9o percent of the first sentences contain at least one /fard/ ( 36 out of 40 ). In the 55 stories from Kwayriš (Meißner 1903: 1-101), only one is not introduced with /fard/; and in 70 percent of the stories ( 38 times), /fard/ is even the very first word of the text.

A typical outset of such a narrative is (19). The first /fard/ introduces the 'framework' (cf. Schroeder 1999: 69) by providing the local setting, whereas the second /fard/ introduces the main character.

(19) Baghdad (McCarthy and Raffouly 1965: 63)

f-fadd gahwa māl haš̌šăš-e čān fadd riğğăl in-INDEF café of hashish.smoker-PL was.3MSG INDEF man $g \bar{a}^{\varsigma} i d$ xa ăll riğl-a ğawwā-h sitting and drawn.up leg-3MSG beneath-3MSG 'In a coffee shop frequented by hashish smokers, a man was sitting with his leg drawn up beneath him.'

Even in this presentative function, which reflects a rather early stage of grammaticalization, the semantic content of /fard/ has been bleached to an extent that it also occurs in NPs with DUAL heads (morphologically and/or semantically). In the introduction to a short anecdote, the three main characters, two

19 McCarthy and Raffouly (1965: 271-289). 
men and one woman, are all introduced with /fard/, as in (20). At least in our corpora, however, /fard/ is not attested in this function with PL heads.

(20) Kwayriš (Meißner 1903: 12/9)

farad rayāğül attnēn yi-mš-ūn bi-d-darub fa-šăf-aw farad INDEF man.PL two 3-go-MPL in-DEF-road and-saw-3MPL INDEF hurme to-hatțib hațab wahad-ha woman 3FSG-collect.firewood firewood alone-3FSG

'Two men walked along the road and saw a woman who was collecting firewood alone.'

Combinations of /fard/ with nouns of time and place like (Baghdad) faddyōm 'one day, fadd lèla 'one night,' fadd marra 'once' and fadd mukān 'somewhere, some place' are often attested in the introductions to shorter or longer narrations. These common adverbial phrases do not introduce the agent or argument of the following discourse, but rather situate the event in a local frame, as in (19) above, and/or temporal frame, as in (21).

(21) Mosul (Jastrow 1979:56/3)

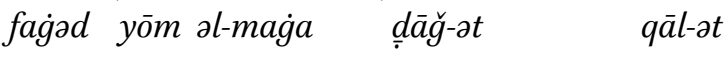
INDEF day DEF-woman was.weary-3FSG said-3FSG 'One day the woman was weary and said ...'

2.5.2 Cataphoric introduction of a new and noteworthy referent Derived from its introductory function in narratives, the use of /fard/ has expanded in the sense that it serves as a cataphoric introduction of a referent that becomes a topic or remains referentially persistent in the following discourse. The item thus marked does not only appear at the beginning of an episode, but also at any other point of a narrative passage ${ }^{20}$ Still, the marked item is always new for the hearer and important for the subsequent discourse. We assume that the almost stereotypical occurrence of /fard/ at the beginning of anecdotes, narratives and the like has resulted in its use in the type of utterances for which some European languages allow an indefinite use of proximal demonstratives. Casual English this, for example, is often used when its referent is noteworthy and it signals "particular, interesting, new information" (von Heusinger 2019: 155). The same can be said of /fard/ in usages as in (22).

20 Cf. Heine (1997: 75) regarding the developments of Old English sum and an. 
(22) Khuzestan (corpus Leitner)

čān-at farad zōd-e xad-at xūzestān, kall xūzestān was-3FSG INDEF flood-F took-3FSG Khuzestan all Khuzestan 'There was this flood. It affected Khuzestan, all Khuzestan.'

Such referents are necessarily always specific and, in the overwhelming majority of occurrences, known to the speaker but not the hearer. In Dryer's terminology (2014: e236), such an NP is a pragmatically specific indefinite and mainly serves to establish a following definite. This is well shown in (23): the first noun marked by /fard/ is referred to by a resumptive pronoun, while the second noun marked by /fard/ is anaphorically referred to by the same noun, but this time marked as definite.

(23) Kwayriš (Meißner 1903: 46/13f.)

wa- 'ida ğāy-a Sala farad bēt čabir w- bīh farad suddenly come.AP-F to INDEF house big and in-3MSG INDEF bint ittla-it il-bint li-l-wulad.

girl came.out-3FSG DEF-girl to-DEF-boy

'Suddenly she (the mare) came to a big house and in it was a girl; the girl came out to the boy.'

In summary, we can state that there is a clear tendency to mark an NP with /fard/ when it provides new information that becomes an antecedent for anaphoric reference. As will be shown in more detail in $\S 4.2$, this presentative function is the one most frequently attested in our corpora.

\subsection{Individual' $\rightarrow$ 'one single' $\rightarrow$ presentative marker $\rightarrow$ individuation marker}

In Iraqi and Khuzestani Arabic, the use of /fard/ goes beyond mere presentative use, as /fard/ can also mark NPs that have either specific or non-specific referents and that do not introduce a new or noteworthy element. The use of /fard/ often signals that the following noun is somehow individuated. Thus, its function is both cataphoric and slightly partitive. The first, because it tells the hearer that further information on the referent is to follow, the second in the sense that the scope of possible referents within the subset is narrowed by means of additional specification. In example (24), the verb štarēt 'I bought' governs three subsequent direct objects. Of these, the unmarked nouns mēz and kursi are only type-identifiable-i.e., the hearer is only "able to access a representation of the type of the object described by the expression" (Hedberg et al. 2019: 103). The noun lampa is marked by /fard/, which signals to the hearer that more 
information will follow, and indicates that it is not any lamp, but one of those whose light is strong. The 'lamp' is semantically further modified and thus more individuated, whereas 'table' and 'chair' remain completely unspecified.

(24) Kirkuk (elicited)

ilbārḥa rịh-it l-is-sūg $\quad w \quad$ štarē-t-l-i $\quad \emptyset m \bar{e} z$ yesterday went-1SG to-DEF-market and bought-1SG-for-1SG table $w \varnothing$ kursi $w$ fadd lampa duwā-ha qawi. and chair and INDEF lamp light-3FSG strong 'Yesterday I went to the market and bought (myself) a table, a chair and a lamp that has a strong light.'

Thus, /fard/ is frequently found with nouns followed by an adjectival attributive, a relative clause (often with anaphoric pronouns as in (24) above) and qualifying appositions such as "named" as in (25).

(25) Baghdad (Al-Karmalī 20og:153/10)

w-akuš [sic!] b-al'M $M^{\varsigma} a d \underline{d}$ d̦am farad mukān 'asm-a qal'at and-there.is in-PN INDEF place name-3MSG castle l'M $M^{\text {saddam. }}$.

$\mathrm{PN}$

'In al-Mu'ad̦dịm there is a place named al-Mu'ad̦diam Castle.'

For the same reason, the use of /fard/ is much more likely when the first sentence continues as in (26a) than in (26b). In (26b), /fard/ is accepted by native speakers but its use implies that the adjective is perceived to be less an attribute than a predicate of the preceding šuqqa 'apartment.'This again indicates its cataphoric function in such utterances.

(26) Baghdad (elicited)

samm-i $\quad b a^{\varsigma} d-a \quad a^{\varsigma} z a b$

uncle-1SG still-3MSG unmarried

a. $w$ sākin ib-fadd šuqqa żgayr-a qarīb-a min

and living in-INDEF apartment small-F close-F to

iğ-ğàmifa.

DEF-university

'My uncle is still unmarried and lives in a small apartment that is close to the university.' 
b. $w$ sākin ib-(fadd) šuqqa żंayyr-a. and living in-(INDEF) apartment small-F 'My uncle is still unmarried and lives in a small apartment (in an apartment that is small).'

Further semantic specification of a noun usually implies a shift of focus away from the event to the argument of the sentence. This general shift seems to be reinforced by /fard/, as illustrated in the next example. While (27a) focuses more on the speaker's activity and excludes the use of /fard/, (27b) stresses the length of the letter and names its addressee - a typical context that triggers the use of /fard/, as it signals that further information on the letter will follow.

(27) Baghdad (elicited)

a. ilbārḥa bi-l-lēl kitab-it ( $\left.{ }^{*} f a d d\right)$ maktūb. yesterday in-DEF-night wrote-1SG letter 'Yesterday evening I wrote a letter.' (And then I went to bed.)

b. ilbārḥa bi-l-lēl kitab-it fadd maktūb tawīl lyesterday in-DEF-night wrote-1SG INDEF letter long to umm-i.

mother-1SG

'Yesterday evening I wrote a long letter to my mother.'

Example (28) demonstrates that non-specific referents may also be marked by /fard/ when they are individualized with an attribute or a relative clause. Without such an element, the use of /fard/is considered to be ungrammatical, as shown in (28a). Only the apposition of the qualifying element battiniyye internal' allows marking with /fard/, as in (28b). In sentence (28b), /fard/ and the co-referential dative (see $\S 4.5$ ) add the nuances of 'politeness' and 'free choice' (see $\S 2.7)$ to the question.

(28) Kirkuk (elicited)
a. ta- $^{\text {' }}$ if
(*fadd) țabīb?
2MSG-know
doctor

'Do you know a doctor?' [Because my daughter is sick.]

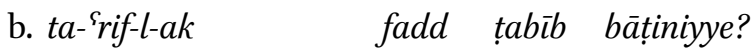

2MSG-know-for-2MSG INDEF doctor internal

'Do you know an (any) internist?' [Because my daughter is sick.] 


\subsection{Individual' $\rightarrow$ 'one single' $\rightarrow$ presentative marker $\rightarrow$ individuation marker $\rightarrow$ epistemic specificity}

In a further step that is motivated by subjectification, /fard/ may be used to mark nouns that are not further qualified for expressing epistemic specificity. In other words, the use of / fard/ indicates that the referent is individuated and specific for the speaker. It has been shown that epistemic specificity is of a purely pragmatic nature, as both the speaker and hearer may obtain enough information during the conversation to identify the referent (von Heusinger 2002: 265). The question in (29) is typically uttered using /fard/ when the speaker is in search of her/his lost cell phone. Since, for the speaker, the cell phone is a unique and hence individuated referent, the question would sound strange if formulated without /fard/.

(29) Kirkuk (elicited)

ligè-t fadd mōbayl ihnā?

found-2MSG INDEF cell.phone here

'Have you found a cell phone here?' [Yesterday I forgot mine here.]

\section{8 'Individual' $\rightarrow$ 'one single' $\rightarrow$ presentative marker $\rightarrow$ individuation marker $\rightarrow$ epistemic specificity $\rightarrow$ epistemic non-specificity}

In questions and in the case of deontic modality, particularly with imperatives, /fard/ may also express epistemic non-specificity. ${ }^{21}$ For instance, the referent is not known or of importance to the speaker and therefore permits a free choice interpretation by the hearer (cf. Alonso-Ovalle and Menéndez-Benito 2013:117). In this particular function, /fard/ often corresponds to German irgend indefinites (cf. Aloni and Port 2015) and may be seen as an example of grammaticalization via intersubjectification, as it leaves the choice to the hearer. In (3o), a mother tells her son to look for a woman, so that he can finally get married.

(30) Khuzestan (elicited)

šüf-l-ak farad mara w-atzawwağ

look.IMP.MSG-for-2MSG INDEF woman and-marry.IMP.MSG

'Find yourself a woman and get married!'

In (31), the speaker tells the addressee to take any donkey to fulfill his task.

21 For imperatives and free choice interpretation, see also Haspelmath (1997:50). 
(31) Kwayriš (Meißner 1903: 8)

inta 'ixid-il-ak ${ }^{22}$ farad muți

2MSG take.IMP.MSG-for-2MSG INDEF donkey

wi-xalli-h b-il-wagfe māl il-mičāriyya

and-leave.IMP.MSG-3MSG in-DEF-place of DEF-renter.PL

'Take any donkey and leave it at the place of the renters!'

2.9 'Individual' $\rightarrow$ 'one single' $\rightarrow$ presentative marker $\rightarrow$ individuation marker $\rightarrow$ epistemic specificity $\rightarrow$ epistemic non-specificity $\rightarrow$ mitigating device

Grammaticalization can also be seen as the result of a problem-solving process. One of these problems is "the search for ways to regulate communication and negotiate speaker-hearer interaction" (Hopper and Traugott 2003: 92). /fard/ has acquired a function that is comparable to particles expressing politeness in other languages (see Brown and Levinson 1987). Polite behavior is characterized by the need to pay constant attention to intersubjectivity. This is particularly important with requests and commands, especially if the command is uttered by a socially subordinate person.

Iraqi and Khuzestani Arabic possess a wide array of politeness phrases and address forms. These are predominantly used as on-record positive politeness strategies (for this concept, cf. Brown and Levinson 1987: 101-129), mainly in direct speech acts that include imperatives-i.e., a "mapping of grammatical form to illocutionary function" (Archer 2017: 386). Bald on-record strategies, particularly the use of bare imperatives, are not principally regarded as rude (similar to, for example, Polish; see Cutting 2015: 67), but many speakers tend to soften them. As spoken Arabic lacks a subjunctive mood, many of the negative politeness strategies expressed with indirect speech acts—such as the English could, would, might, etc.- -are not an option (see Brown and Levinson 1987:134144 for their use in English and other languages).

Thus, in certain contexts, /fard/ may be used as a device for mitigation and hedging. Marking with /fard/ adds a nuance of modesty to a request or command, as the speaker indicates that the request can be complied with easily and without much effort. We presume that this function developed via intersubjectification from its usage to mark non-epistemic indefiniteness, because a request or command that leaves the quality and kind to the addressee's discretion is possibly perceived to be less strict than clear instructions. The avoidance of giving precise content and leaving an option open to the addressee is often 
found with hedges-e.g., English kind of, sort of, somehow, etc. (Watts 2003: 183). The imperative in (32), even if used without the politeness formula, is perceived to be less harsh than without /fard/. Typically, it would be uttered by a child to his/her father, but not vice versa, as the father can give clear orders to his children.

(32) Baghdad (elicited)

ğĭb-l-i fadd glāṣ (bala zaḥme!)

bring.IMP.MSG-to-1SG INDEF glass without trouble

'Bring me a glass, please!'

The imperative in (33), addressed to the first author of this paper, is to be understood as a suggestion rather than a command.

(33) Khuzestan (corpus Leitner)

$x a d-i \quad m a n-h a$ farad filim!

take.IMP-FSG from-3FSG INDEF video

'Make a video of it (if you'd like to).'

/fard/ is also used as a mitigating device in requests, usually in addition to other strategies like forms of address and indirect speech (question + possibility; assertion + negation). In (34), marking with /fard/ mitigates the straight expression of the wish-i.e., 'I want' (there is no equivalent verbal expression for English I would like to in the dialect).

(34) Kwayriš (Meißner 1903: 30/7)

yā ḥurma a-rīd a-nšad-ič farad su'āl

VOC woman 1SG-want 1SG-ask-2FSG INDEF question

'Madam, I would like to ask you a question.'

In (35), indirect speech negation (for similar examples in English, Tamil and Tzeltal, see Brown and Levinson 1987: 137) is used as a politeness strategy that can be reinforced with /fard/. As rās țüm explicitly means 'one bulb of garlic' (lit. 'one head of garlic'), the use of /fard/ is redundant for expressing the number of bulbs, but just makes the request sound nicer.

(35) Baghdad (McCarthy and Raffouly 1965: 123)

ma t-gūm-ìn iğ-ğ̌̀b-i-n-na fadd rās țūm minnā?

NEG 2-get.up-FSG 2-bring-FSG-for-1PL INDEF head garlic from.here

'Won't you please get up and bring us a bulb of garlic from there?' 
(36) is an illustrative example of a request that is put forward indirectly. The double use of /fard/ makes it sound more polite, which is important when asking a friend for a larger sum of money. Here, /fard/ with the following numeral does not serve as a form of approximation (cf. § 2.4), but rather as a hedging device. This becomes clear in the following part of this dialogue: when the addressee asks the speaker, "How much?" he responds that he needs exactly 5 o dinar, which he could pay back within two months.

(36) Baghdad (McCarthy and Raffouly 1965: 89)

șār-at sid-na fadd muškila wi-b-lāzim-ni fadd xamsin became-3FSG at-1PL INDEF problem and-in-need-1SG INDEF 50

dīnār.

dinar

'We've got a problem, and I need fifty dinars.'

Offers can also be marked with /fard/ to add a nuance of friendliness toward and appreciation of the person addressed. In (37), a man offers to help a friend marry his beloved.

(37) Baghdad (McCarthy and Raffouly 1965: 107)

a-rìd a-sawwi-l-ak fadd xidma.

1SG-want 1SG-make-for-2MSG INDEF service

'I want to do you a service.'

In (38), the owner of a barber shop offers his client something to drink and suggests a cup of tea to him. To be polite, he marks the noun čāy with /fard/. Note how in this example fadd assimilates to the following palato-alveolar affricate $\check{c}$ (yielding fač).

(38) Baghdad (McCarthy and Raffouly 1965:56)

Abu $\dot{G} a \bar{a} l i b$, fać-čāy

PN INDEF-tea

'Abu Ghalib, would you like to have some tea?'

The same function of polite offering underlies the short dialogue that Haim Blanc cites to emphasize the complexity of the use of /fard/, cited here in (39). The use of "please!" adds sufficient politeness in the first offer, while /fard/ makes the offer more courteous in the second question. 
(39) Baghdad (Blanc 1964: 119)

tfạ̦ḍal ğigāra? - la? a-škur-ak. - fadd gahwa?

please cigarette no 1SG-thank-2MSG INDEF coffee

'A: "Have a cigarette?"-B: "No, thank you!"-A: "A cup of coffee?"'

A functionally similar but cross-linguistically more widespread phenomenon is the use of diminutive forms for mitigating requests (see Dressler and Merlini Barbaresi 1994: 123). It is also attested in Arabic dialects, particularly in the Maghreb, where productive diminutive formation is still widespread (cf., for Tunis, Procházka 2019). In Iraqi and Khuzestani Arabic, diminutive formation of nouns is not fully productive, but where a diminutive form is available we sometimes find both mitigating devices combined. The context of example (40) is that a woman and her children, strangers in the town, are looking for a place to stay and ask a man standing in front of a house:

(40) Kwayriš (Meißner 19o3: 24/14)

ni-rīd min 'and-ak fard imčayyin illi ni-gsid āni 1PL-want from at-2MSG INDEF spot.DIM REL 1PL-stay 1SG $w i^{2}{ }^{2} a w l a \bar{d}-i \quad b \bar{\imath}-h$ and-child.PL-1SG in-3MSG

'We would like to have from you a (little) spot where I and my kids can stay.'

Masliyah describes the phrase cited here in (41) as a model for when, "Feeling ashamed and hesitating to ask a favor, one says [this type of sentence] to one's interlocutor."

(41) Baghdad (Masliyah 1999: 97)

ba-ḷa yā Hasan sōlif-il-na fadd sālūfa!

by-God voc Hasan tell.IMP.MSG-for-1PL INDEF story.DIM

'Please, Hasan, do tell us a (any) story!'

\section{$3 \quad$ Constraints and restrictions}

The meaning of the source item of a grammaticalization often persists in the sense that the grammaticalized item is not used in functions that are incompatible with its original meaning (Hopper and Traugott 2003: 96). In addition to a few settings that completely block the use of /fard/, there are some limitations to its use in the sense that / fard/ is only possible under certain conditions. 


\subsection{Constraints upon using /fard/}

/fard/ cannot be used to mark nouns in light verb constructions that only serve to modify the event expressed with the verb-e.g., (42) and (43):

(42) Baghdad (McCarthy and Raffouly 1965: 21)

ti-'urf-in tu-ḍurb-īn (*fadd) ūti.

2-know-FSG 2-hit-FSG iron

'You know how to iron.'

(43) Baghdad (elicited)

fitah-l-i

( ${ }^{*}$ fadd) $f a ̄ l$.

opened.3MSG-for-1SG

auspice

'He told me (my) fortune.'

The use of /fard/ is also blocked for arguments of the preposition /mitl/ 'like,' as in (44a), which is usually followed by a generic and thus DEF-marked noun anyway. ${ }^{23}$ However, a similar utterance made without /miț/ and a semantically enriched referent, as in (44b), allow for indefinite marking with /fard/, as it indicates a kind of intensification ( $\operatorname{see} \S 2.2)$.

(44) Kirkuk (elicited)

a. huwwa bi-n-nisba il-i mitil ( $\left.{ }^{*} f a d d\right)$ șadiq. he in-DEF-relation for-1SG like friend

'He is like a friend to me.'

b. huwwa bi-n-nisba il-i (fadd) șadīq hamìm.

he in-DEF-relation for-1SG INDEF friend close

'He is a (really) close friend to me.'

\subsection{Restrictions related to negation}

In the functions described in $\$ 2.5$ to $\$ 2.9$, the use of / fard/ is highly limited under the scope of negation, which includes arguments of the preposition bala 'without,' as in (45). It appears that this restriction is related to the fact that, in these functions, /fard/ tends to mark referents that play a certain role in the following discourse, which is impossible with non-existent items. ${ }^{24}$

23 For the preposition bala 'without,' see the next section.

24 The same is reported for casual Modern Hebrew, which does not allow use of -xad in negated utterances either (Givón 1981: 40). 
(45) Kirkuk (elicited)

bala ("Fadd) qalam ma ${ }^{2} a$-gdir a-mli l-istimāra.

without pen NEG 1SG-can 1SG-fill.out DEF-form

'I cannot fill out the form without a pen.'

There are no or at least fewer restrictions regarding negation in other functions, particularly when /fard/ is used to express singularity (§ 2.1). Also, the two indefinite pronouns (see §3.3.3.1 below) —/fard wāhid//in (46) and /fard šil in (47) - are attested in the scope of negation, which is a likely indication that these compound forms have undergone a further grammaticalization process. In both cases, the addition of / fard/ implies a nuance of emphasis of the negation, which suggests that this usage is connected to that of an intensifier $(\S 2.2)$.

(46) Kirkuk (elicited)

'Ali ma ya-'ruf fadd wāhid $y$-'sallm-a 'almāni.

PN NEG 3MSG-know INDEF one 3MSG-teach-3MSG German

'Ali doesn't know anybody who (could) teach him German.'

(47) Kwayriš (Meißner 19o3: 8o/41-42)

'inta t-ākil $\min$ ğamī' l-alwān $\quad w_{\text {-'ānni } a-f u k k}$

2MSG 2MSG-eat from all DEF-sort.PL and-1SG 1SG-open

halg-i Sala l-hawa mā 'ākil farəd ši.

mouth-1SG for DEF-air NEG 1SG-eat anything

'You eat from all sorts of things and I should open my mouth for (getting only) air (but) nothing to eat?'

\subsection{Other semantic and formal restrictions}

Even in the majority of languages that possess a full-fledged indefinite article, it is often not used for marking mass nouns, abstract nouns or plural nouns. In general, the use of /fard/ with such nouns appears to be limited, too, albeit allowed in certain contexts, which are described in the following.

\subsubsection{Marking of uncountable singular nouns}

In Iraqi and Khuzestani Arabic, this usage of /fard/ is restricted to its function as an intensifier (§2.2). In most cases, such utterances also contain adverbs or phrases that express intensification and thus reinforce the intensifying value. In the short dialogue of (48), the person asked about her state of health wants to emphasize the violent degree of her headache. Thus, the abstract noun wuğ $a^{\varsigma}$ 'pain' is marked by /fard/ and specified by the relative clause $m \bar{u} t a b \imath^{-} i$ 'not 
normal/natural'. Most native speakers would not use /fard/ in this utterance without this specifying attribute..$^{25}$

(48) Kirkuk (own data)

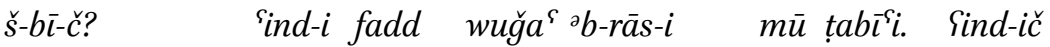
what-with-2FSG at-1SG INDEF pain in-head-1SG not normal at-2FSG il-sāfya!

DEF-health

A: 'What's wrong with you?-B: I have a really bad headache.-A: Get well!'

In (49), the mass noun māy 'water' is marked by /fard/ to emphasize the good quality of water in a certain place, implicitly contrasting it with the bad water elsewhere.

(49) Nasiriyya (elicited)

hāda fadd māy hilu!

DEM INDEF water good

'This is really good water!'

3.3.2 Marking of plural nouns

There is also evidence of the usage of /fard/ with PL heads. Thus, its original meaning, 'individual person/thing,' has become so attenuated that there is no semantic incompatibility perceived between it and plurality-something which Heine (1997: 78) subsumes under "extreme cases" in the development of indefinite articles.

Compared to its usage with SG nouns, the use of /fard/ with PL heads is very rare and constitutes only $2.1 \%$ of all occurrences (for details, see $§ 4.2$ ). In most cases, /fard/ with a PL head corresponds to English 'some' and thus resembles an indefinite quantifier (see also § 2.4). It appears that the option to use /fard/ with PL heads has largely evolved in accordance with its most common function with SG heads, which is to introduce new referents (see $\S 2.5$ and $\S 4.1)$. A typical example of that is $\left(5^{\circ}\right)$ taken from a traditional narrative:

25 Another attested phrase with an abstract noun (likewise from Kirkuk) is fadd $x \bar{o} f m \bar{u} t a b \bar{\imath}^{\varsigma} i$ 'an abnormal fear'. 
(50) Kwayriš (Meißner 1903: 48/10-11)

wə-šăf farad xțub-ät wə-liga ğawwa l-ixțub-āt

and-saw.3MSG INDEF wood-PL and-found.3MSG under DEF-wood-PL farad $\check{g} \bar{u} d$ màl mōy

INDEF skin of water

'He saw some pieces of wood and beneath the wood he found a water skin.'

A second function that has been transferred to plural nouns is to mark nonspecificity $(\S 2.8)$-i.e., the speaker expresses that s/he does not know the referents, as in (51).

(51) Khuzestan (corpus Leitner)

man nām-at, Pahna hadann radd-an Paya sēkāri when sleep-3FSG 3FPL DEM.FPL came.back-3FPL came.3MSG seller $y$-bīs farad lasābì-yāt

3MSG-sell INDEF toy.PL-PL

'While she slept, they (her friends) came back; and a seller came, who sold some toys.'

In (52), marking with /fard/ also implicates free choice for the hearer and adds a nuance of politeness to the question (see $\S 2.9$ ).

(52) Baghdad (Erwin 1963: 356)

'aku sind-ak fadd kutub zēn-a 'a-qra bi-ha

there.is at-2MSG INDEF book.PL good-F 1SG-read in-3FSG

bi-l-'^utla?

in-DEF-holiday

'Have you got some good books I can read on vacation?'

3.3.3 Marking of word classes other than nouns

3.3.3.1 Indefinite pronouns

There are four items marked by /fard/ that serve as a kind of indefinite pronoun: /fard wāḥid/ 'someone, anyone,' /fard šì/ 'something, anything,' /fard šwayya/ 'a little' and /fard čam/ 'a few, several.'26 One notices that, in all of these compound forms, /fard/ is attached to lexical items that can be used on their own in the same function and render the same meaning —e.g., / wāhid/ 'someone, any-

26 The last two are not attested in our corpora. 
one.' Therefore, /fard/ is not another example of a source item for the grammaticalization of indefinite pronouns such as English someone, French quelqu'un and German irgendeiner (see also Kuteva et al. 2019: 301). That is because it is not /fard/ 'one single,' but /wāhid/ 'one' that serves as the base word; /fard/ only modifies this and other pronouns according to its grammaticalized usage. Therefore, the two compound pronouns /fard wāḥid/ and /fard šì/ are always found in contexts that correspond to other functions of /fard/. In our corpora, the most frequently attested form and function of these compound indefinite pronouns is /fard wāhiid/ in a presentative function (see § 2.5) introducing narratives and anecdotes, as in (53).

(53) Basra (Denz and Edzard 1966: 79/1)

fadd wāhid kān yōmiyya ${ }^{27}$ huwwa bayyā $\bar{a}^{\varsigma}$ băğilla w-hāda INDEF one was.3MSG daily 3MSG seller beans and-DEM yōmiyya lāzim kān $\quad y$-ākil bāğilla

daily must was.3MSG 3MSG-eat beans

'(Once upon a time,) there was someone-he was a seller of beans-he had to eat beans daily.'

Further modification by /fard/ gives the indefinite pronouns /wāḥid/ and /šî/ an additional nuance of non-specificity, often corresponding to German irgend- (see § 2.9). In (54), the person who should be sold as a slave does not, of course, know who will buy him and says to the person who wants to sell him:

(54) Kwayriš (Meißner 1903: 92/13)

balčin farad wāḥid yi-ği $y$-āxid-ni

perhaps INDEF one 3MSG-come 3MSG-take-1SG

w-yi-nți-k il- ${ }^{2} a l i f$ dīnār.

and-3MSG-give-2MSG DEF-1,ooo dinar

'Perhaps someone will come and buy me and will give you the 1,0oo dinar.'

The compound /fard wāhid/ may also modify a following noun in the sense of 'some'. This is only possible when the modified noun is [+HUMAN], often an ethnonym. Most occurrences are again found at the beginning of narratives, as in (55).

27 The clause has a break here, and the next three words are an insertion. Therefore, 'daily' was translated only once. 
(55) Kwayriš (Meißner 1903: 42/14)

'aku farad wāhid iM'êdi gāl

there.is INDEF one MiSdan.Arab said.3MSG

'There was some MiYdan-Arab ${ }^{28}$ who said ...'

It is worth mentioning that /fard/ can modify more than just /wāhid/ 'one'. There are also occurrences in which it is combined with the numeral "two". In contrast to /wāhid/, the numeral /itnēn/ 'two' is not used independently to express "two (persons)." 29 Thus, in examples like (56), a "pronoun" meaning 'some two (men)' can only be formed with the addition of /fard/.

(56) Baghdad (McCarthy and Raffouly 1965: 63)

fadd itnēn čān da-yi-tmašš-ūn b-ǐs-šāris iğ-at

INDEF two was.3MSG PROG-3-walk-MPL in-DEF-street came-3FSG

sayyāra $w$-di'm-at-hum

car and-struck-3FSG-3MPL

'Two (men) were taking a walk on the street. A car came and struck them.'

\subsubsection{Numerals}

In certain functions, /fard/ can be used with numerals: either to express approximation $(\$ 2.4)$ or to modify the indefinite pronoun 'one.' There are also occasional examples in which /fard/ is the first element of a compound indefinite pronoun based on the numeral 'two' (see example (56) in the preceding section).

3.3.3.4 Verbs

In its function as a scalar adverb meaning 'only' /fard/ can-though rather infrequently—also be used with verbs (cf. example (12) in § 2.3).

Analysis and discussion

4.1 Frequency

While the marking of an indefinite NP with /fard/ in a given utterance is difficult to predict, it is not arbitrary. In our corpora, the relative frequencies of the different functions of /fard/ that developed from different stages and pathways

28 Today usually referred to as Marsh-Arabs: the inhabitants of the swamps in southern Iraq and Khuzestan.

29 See example (20) above. 
TABLE 1 Absolute and relative frequencies of the lexeme / fard/ according to its main functions

\begin{tabular}{|c|c|c|c|c|c|c|c|}
\hline & Baghdad & al-Ḥilla, etc. & Khuzestan & Kwayriš & Mosul & Total & Percentage \\
\hline Number of words & 41,200 & 1,600 & 35,000 & 15,500 & 7,600 & 100,900 & \\
\hline Singularity $(2.1)$ & 4 & o & 6 & 7 & 1 & 18 & $3.5 \%$ \\
\hline Intensifier $(2.2)$ & 3 & o & 4 & 8 & 1 & 16 & $3.1 \%$ \\
\hline Adverb "only" (2.3) & 1 & o & 2 & 2 & o & 5 & $1.0 \%$ \\
\hline Approximation (2.4) & 15 & o & 3 & o & 6 & 24 & $4.7 \%$ \\
\hline Presentative (2.5) & & & & & & & $63.3 \%$ \\
\hline - Narrative introduction $(2.5 \cdot 1)$ & 43 & 7 & 7 & 65 & 1 & 123 & $23.9 \%$ \\
\hline - Cataphoric $(2.5 .2)$ & 74 & 4 & 36 & 84 & 5 & 203 & $39 \cdot 4 \%$ \\
\hline Individuation (2.6) & 13 & o & 9 & 6 & 1 & 29 & $5.6 \%$ \\
\hline Epistemic spec. (2.7) & 9 & o & 5 & 7 & o & 21 & $4.1 \%$ \\
\hline Epistemic non-spec. (2.8) & 15 & o & 6 & 6 & o & 27 & $5.2 \%$ \\
\hline Mitigating device (2.9) & 41 & o & 2 & 6 & o & 49 & $9.5 \%$ \\
\hline Total & 218 & 11 & 80 & 191 & 15 & $5^{15}$ & $100.0 \%$ \\
\hline Percentage of /fard/ & $0.53 \%$ & $0.69 \%$ & $0.23 \%$ & $1.23 \%$ & $0.20 \%$ & $0.51 \%$ & \\
\hline
\end{tabular}

of grammaticalization are rather unbalanced. The numbers may therefore provide indications of how likely it is that a speaker will use /fard/, as the optional nature of /fard/ does not mean that the frequency of its use is randomly distributed across its different functions. Hopper and Traugott (2003: 106) state that the more frequently a form occurs in texts, the more grammatical it is, which means that frequency demonstrates a kind of generalization in usage patterns (see Table 1).

When interpreting these numbers, it is important to consider the genre of the given corpus. The much higher rate of /fard/ in the texts from Kwayriš (almost three times higher than in Baghdad and five times higher than in Khuzestan) cannot be explained by dialectal differences, but results from the fact that this corpus mainly contains stories and anecdotes. In texts that do not narrate events, but describe processes and procedures (e.g., recipes), /fard/ is almost absent, except for fixed phrases like /fard mudda/ 'a certain time', or for expressing numerical approximation. ${ }^{30}$ In dialogues, which are underrepresented in our corpora, the frequency of / fard/is about half the number found in

30 See, for example, the three recipes in McCarthy and Raffouly 1965: 34-36 (2 instances in approx. 1,00o words); the text on baking bread from Mosul in Jastrow 1991 (zero instances in approx. 1,300 words), the recipes from Mosul in Jastrow 1979: 64-75 (3 instances in approx. 1,400 words). All five occurrences belong to the two categories mentioned in the text. 


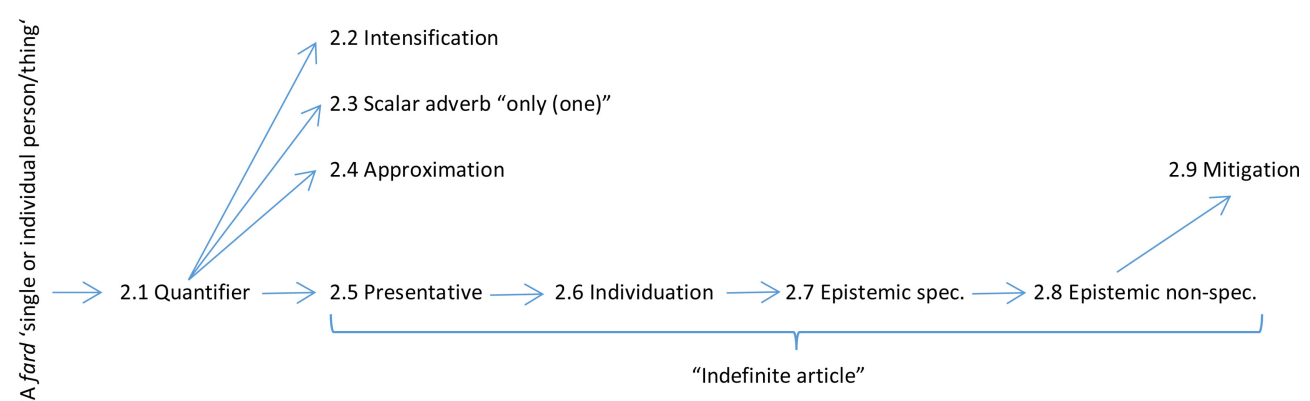

FIGURE 2 Possible grammaticalization scales of /fard/

narratives, though functions related to intensification and mitigation are more common in conversations than in stories and anecdotes. Nevertheless, its presentative function remains the most common one even in these sorts of texts.

\subsection{Grammaticalization scales of /fard/}

In this section we will discuss general aspects of the grammaticalization pathways of /fard/ proposed in $\S 2$ (see Figure 1, which, for clarity, is presented again in this section as Figure 2 with only minor additions). We are aware that any grammaticalization scale (also called "chain," "pathway," "cline," "continuum," etc.) has "a chain-like structure which cannot easily be divided into more or less separable 'points" (Kuteva et al. 2019: 8). A typical scale or cline is "content item $>$ grammatical word $>$ clitic $>$ inflectional suffix" (Hopper and Traugott 2003: 7). As for /fard/, it has mainly undergone the first stage only, though it shows some tendencies toward proclitic usage, particularly in Baghdadi Arabic.

The large variety of functions covered by /fard/ suggests that they are the result of "poly-grammaticalization"-i.e., "multiple developments, where a single form develops different grammatical functions in different constructions" (Hopper and Traugott 2003:114-115), leading to the existence of several "forks" on the "pathway" of the grammaticalization of /fard/.

It can be supposed that the poly-functional character of /fard/ is the result of more or less independent grammaticalization processes, all of which began in the first stage, when it became a quantifier that marks singularity $(\S 2.1)$. In this stage of the grammaticalization pathway, which is already present in Classical Arabic (cf. § 2.0), the meaning of the source item 'individual' shifted only slightly to 'one single,' which is typical for an initial phase of grammaticaliza- 
tion (Hopper and Traugott 2003: 94-95). In this function, /fard/ is found rather infrequently $(3.5 \%)$ in our corpora, which can easily be explained by the fact that emphasis of the number "one" does not occur very often.

A direct path from a quantifier to an intensifier $(\S 2.2)$ seems very likely. Similar usages of the numeral "one" are attested in other Arabic dialects and Neo-Aramaic (Khan 1999: 202 f.). It is also found in German ${ }^{31}$ and several Slavic languages (Belaj and Matovac 2015:8, fn. 10 and 15 f.; Breu 2012: 295). In Iraqi and Khuzestani Arabic, this function is usually enhanced with a particular intonation contour. Its relative frequency in our corpora is only 3.1\%, though it could occur much more frequently in conversations - an assessment confirmed by native speakers. When /fard/ expresses emphasis, even uncountable abstract and mass nouns can be marked. ${ }^{32}$

The grammaticalization into a scalar adverb in the sense of 'only' (§2.3) has probably developed from the meaning 'only one' under the influence of the intensifying function of /fard/. With merely $1 \%$ of all occurrences in our corpora, it is the least common function of all. The frequency of use of the adverb bass 'only' - a lexeme that is ultimately of Persian origin — by far outweighs that of /fard/ in this function.

A function that is well attested in almost every corpus is the use of /fard/ to express numerical approximation and vagueness ( $\$ 2.4)$. Its relative frequency is $4.7 \%$, which is remarkable given that it is restricted to one morphological category. As exemplified in $\S 2.4$, the grammaticalization of "one" in this context is a widespread cross-linguistic phenomenon.

Table 1 strikingly shows that the by far most common function of /fard/ is that of a presentative marker ( $(2.5)$ : in $63.3 \%$ of all occurrences, /fard/ is used to introduce a new and noteworthy referent. The three functions described in $\S 2.6$ to $§ 2.8$ are closely related and must have developed from the former via further steps in the grammaticalization process. The percentages of their frequency are rather balanced, ranging from $4.1 \%$ for epistemic specificity $(\S 2.7)$ to $5.2 \%$ for epistemic non-specificity $(\S 2.8)$ and $5.6 \%$ for individuation $(\S 2.6)$.

A purely pragmatic function of /fard/ is that it can serve as a form of mitigation and hedging $(\S 2.9)$, particularly in conversations. This function is relatively common (9.5\%). The data of our corpora suggest that it is more widespread in Iraqi (especially Baghdadi) Arabic than in Khuzestani Arabic. However, this question requires further investigation.

$31 \quad$ For example, Du bist mir ein Gauner! 'You are a real rascal!.

32 The same is also common in German-e.g., Mensch, habe ich eine Angst gehabt! 'Man, was I afraid! (lit. got a fear)' (Breu 2012: 286). 
As was mentioned in $\S 3.3 .2$, /fard/ is also used in combination with countable plural nouns (roughly corresponding to English some). Such usage implies a further step of semantic bleaching and likely reflects a later stage of grammaticalization. This would also explain its rather infrequent occurrence in our corpora (11 out of 515 ; i.e., $2.1 \%$ ), which may be seen as an indication that this stage of grammaticalization took place more recently. General studies on articles (particularly Becker 2018) have shown that even pure presentative articles (which can never be used with specific referents) are not always restricted to SG usage. This corroborates our assumption that the extension of the usage of /fard/ with PL heads has developed directly from the stage as a presentative marker ${ }^{33}$ and was then extended to usages related to epistemic non-specificity and mitigation (for details, see Becker 2018: 151).

\subsection{The grammaticalization processes of /fard/}

As shown in the preceding sections, the development of /fard/ reflects two pragmatic-semantic processes that are essential for grammaticalization (Narrog and Heine 2018:1): (1) "extension"-i.e., the use of an item in new contexts, and (2) "desemanticization"-i.e., loss or generalization in meaning content. These two processes always precede phonetic reduction, a rule that is also reflected in the case of /fard/. All regions show more or less the same processes of grammaticalization, though the phonological structure of the source item has remained unchanged in most regions. Only in the Central Iraqi dialects (and from there spreading southwards) has fard been shortened to fadd (and fad); for Baghdad there is even evidence that fadd has become a clitic that shows assimilation of the final $-d$ to following (palato-)alveolar and dental consonants-e.g., fas-safra 'a journey' in (61).

/fard/ is a good example of the principle of "layering" (Hopper 1991: 22), as new and old layers co-exist. "Divergence" (Hopper ibid.) can be found in Iraqi Arabic, because the source item fard, PL 'afräd, 'individual' is in use, though it is highly likely that this meaning has not been retained, but instead entered the dialect rather recently via Modern Standard Arabic. ${ }^{34}$ Semantic bleaching as a typical feature of grammaticalization (cf. Hopper and Traugott 2003, Heine and Reh 1984) is prominently attested by the option to use /fard/ with PL heads $(\S 3.3 .2)$ and for approximation with numerals (§2.4).

The direction of semantic change is always from non-subjective to subjective (Traugott 2009: 126-128), which is also reflected in the development of 
/fard/. Subjectification is responsible for several stages: from a marker of singularity $(\S 2.1)$ to a marker of intensification and emphasis $(\S 2.2)$, and to the use of /fard/ as a scalar adverb meaning 'only' ( 2.3). Likewise, the expression of approximation ( $(2.4)$ involves subjectification.

Intersubjectification historically arises out of subjectification; hence, it occurs at the very right end of the grammaticalization scale. Intersubjectification involves hearer orientation and is typically found with discourse markers serving as hedges (Traugott 2009: 130). It also implies paying attention to the hearer's "face" and thus may include polite behavior. This explains the use of /fard/ for the expression of epistemic non-specificity ( $\$ 2.8)$ and its development toward a mitigating device in commands, requests and offers ( $\$ 2.9)$.

The frequent use of /fard/ as a presentative marker ( $\$ 2.5)$ can be seen as "pragmatic enrichment" (cf. Hopper and Traugott 2003: 94). The often stereotypical use at the beginning of narratives may suggest that /fard/ has undergone a process of objectification (or desubjectification) - i.e., semantic widening that leads to a "loss of the expression of emphasis, discourse importance, remarkability" (Breban 2015: 168; see also Waltereit 2012: 66).

Last but not least, it is worth mentioning that contact with other languages, particularly Neo-Aramaic, Turkish (Ottoman and Turkmen) and Persian has very likely played an additional role in some of the grammaticalization processes of /fard/. This question will be dealt with in a separate article.

\subsection{Is Ifard/an indefinite article?}

As was mentioned in the introduction, /fard/is labelled as an "indefinite article" in nearly all grammars and handbooks. There can be no doubt that the functions described in $\S 2.5$ to $\S 2.8$ - which constitute $78.2 \%$ of all occurrenceslargely conform to what is usually called an "indefinite article" in European languages. The lexeme /fard/ also shares some other characteristics of indefinite articles. For instance, it cannot be used pronominally in contrast to the numeral "one" (Heine 1997: 81-82). However, there are also striking differences between /fard/ and the indefinite articles that have developed particularly in the Germanic and Romance languages, most notably the obligatoriness of their use in many contexts. We will discuss some of these issues in the light of what was presented in the preceding sections.

In the World Lexicon of Grammaticalization, the Iraqi /fard/ is mentioned as an example of the grammaticalization process "one" $\rightarrow$ "indefinite article" (Kuteva et al. 2019: 300). This entry suggests that Iraqi and Khuzestani Arabic share the common development whereby indefinite articles derive from the numeral "one." This pathway of grammaticalization is found in the great majority of languages (De Mulder and Carlier 2011: 520). In fact, /fard/ constitutes one 
of the few exceptions in that, as the source item, it is not a numeral, but a noun meaning 'individual.' But the etymological origin of /fard/ alone does not, of course, preclude that it eventually evolved into an indefinite article.

Heine (1997) proposed an outline of the different stages of how indefinite articles have evolved. In Stage I, the item in question functions exclusively as a numeral. Stage II is reached when the numeral can be used as a presentative marker. In the "early Stage II situation" (Heine 1997: 72), such a presentative marker usually occurs at the beginning of fairy tales, traditional narratives and anecdotes. From a typological perspective, this is often regarded as the first stage in the development of an indefinite article, as such conventionalized cases of establishing a new and discourse-prominent referent trigger the (compulsory) use of "indefinite articles" even in languages in which such articles exist only in rudimentary form, as in Neo-Aramaic (Khan 1999: 196; Waltisberg 2016: 36) and some Slavic languages such as Russian (Heine 1997: 72), Macedonian (Weiss 2004: 146) and Upper Sorbian (Breu 2012: 281). ${ }^{35}$

In a later Stage II situation, the item is found to introduce "a new participant presumed to be unknown to the hearer" (Heine 1997: 72). In Stage III of the grammaticalization chain of the development of indefinite articles, the article is no longer confined to presentative use, but can mark any indefinite NP that has a specific referent. In Stage IV, the use of the indefinite article is extended to a marker for non-specific referents. ${ }^{36}$ Stage $V$ corresponds to a generalized indefinite article such as Spanish $u n$-, in which case the article can even be used with plural heads (Heine 1997: 73).

As for /fard/, Heine's Stage $I$ is only reached by means of a preceding step of grammaticalization, as it is actually not a numeral. Early Stage II roughly corresponds to the function described in §2.5.1. With referents that are [+HUMAN], this is also widely attested in other Arabic dialects, though not expressed with /fard/, but rather with the numeral /wāhid/ 'one' as the head of the NP (cf. Brustad 2000: 31-33 for Syrian and Kuwaiti Arabic; and Woidich 2006: 212 for Egyptian Arabic). We assume that temporal and local adverbials like fadd yōm 'one day' also go back to this rather early stage of grammaticalization, as they are mainly used to set the "frame" of a narrative. Their English equivalents are also mostly combined with the numeral one and not with the indefinite article a/an.

The Later Stage II situation is reached with the function described in $\S 2.5 .2$. In $\S 4.1$ and $\S 4.2$, we have already seen that this "broadened presentative func- 
tion" represents by far the most frequent use of /fard/. Nevertheless, it cannot be regarded as a mere presentative article (for this term, see Becker 2018: 151) because its development clearly shows further stages. The development from a marker for cataphoric introduction of a new referent to a marker of individuation and epistemic specificity is certainly a very fluid one. In principle, both stages, III and IV, are also attested with /fard/. However, it is usually not the type of referentiality that is decisive for its use in contexts other than presentative introduction. As shown in $§ 2.6$, an important factor for using /fard/ beyond its function as a presentative marker is to signal individuation of an item-i.e., the NP marked by /fard/ exhibits additional semantic specification by means of adjectival attributes and relative clauses with anaphoric anchoring. Thus, we can say that /fard/ functions here as a "phrase-internal" cataphoric device. It signals that the hearer can expect further semantic specification. Such a criterion for using a nominal marker seems to be typical for non-obligatory indefinite articles. The same is, for example, found with the Late Latin numeral unus (Presslich 2000: 186) and in many Balkan Slavic languages, among them Macedonian and Bulgarian, for which Weiss (2004: 157) observes, “Contrary to the plausible predictions of Givón's model (...), referential status turns out not to be decisive, but is partly overruled by a syntactic constraint, viz. further specification of the NP by attributive modifiers or relative clauses. The more we move from left to right on the channel [viz. numeral $\rightarrow$ specific $\rightarrow$ non-specific], the more strongly this constraint makes itself felt." This is mutatis mutandis also true for Iraqi and Khuzestani Arabic, although we interpret specification less as a syntactic than a semantic factor.

/fard/ also combines with PLURAL nouns, though very rarely. In many languages that show the grammaticalization of the numeral "one" into an indefinite article, this has retained some relics of its original semantic meaning in the sense that it is incompatible with plural nouns (Heine and Kuteva 2007: 45). The extension of the use of an indefinite article to plural nouns is therefore not widespread and regarded to be the very last stage in the development of indefinite articles.

In summary, we can say that /fard/ exhibits all of the stages that have been cross-linguistically observed in the development of indefinite articles (though different mechanisms for using it are at work). Therefore, we claim that - with regard to the functions described in $\S 2.5, \S 2.6, \S 2.7$ and $\S 2.8$ - there is good reason to label /fard/ an indefinite article, and even one with a very wide scope. What differentiates it clearly from the systems of indefinite articles found in many European languages is that it is optional to a very high degree. Though it is frequently attested as a presentative marker, there is apparently not a single 
setting that requires it. ${ }^{37}$ This is illustrated well by the following examples, (57) and (58), which are taken from two subsequent sentences of the same story. The two passages narrate an almost identical setting and even share the same noun as their overt subject. Nevertheless, example (58) lacks /fard/.

(57) Baghdad (McCarthy and Raffouly 1965: 116)

aku fadd tāğir min Nașībin sind-a mayy warid kulliš there.is INDEF merchant from PN at-3MSG water roses very fāxir excellent

'There's a merchant from Nisibis who has some very excellent rose water.'

(58) Baghdad (McCarthy and Raffouly 1965: 116)

aku hnā Ø tāğir min Halab sind-a zuğăğ ${ }^{2}$ mḍhhhab there.is here merchant from PN at-3MSG glass gilded bad $\bar{\imath}^{\varsigma} \quad k u l l i s$

wonderful very

'There's a merchant here from Aleppo who has some very lovely gilded glass.'

In any case, the term indefinite article must not be misconstrued in such a way that would suggest that /fard/ is the indefinite counterpart of the definite article /il-/. As in most other varieties of Arabic, indefiniteness in Iraqi and Khuzestani Arabic is still predominantly expressed by the absence of any marker, which means that the system of nominal determination in these varieties is largely different from what is found, for instance, in English. This is also shown by the absolute numbers of its occurrence in the corpora analyzed. In spite of the huge disparities regarding corpora size and type, we believe that even a comparison as rough as this with English reveals the differences in functions, above all the degree of the obligatoriness of its usage.

- Iraqi and Khuzestani Arabic: 403 out of 100,900 (0.4\% of all words) ${ }^{38}$

- British National Corpus ( $a$ tagged as article):2,136,923 out of 100 million (2.14\% of all words)

- Corpus of Contemporary American English: 12,546,599 out of 56o million (2.24\% of all words)

37 However, it is Standard Average European, and not Iraqi and Khuzestan Arabic, that is peculiar, as articles are not required in the vast majority of the world's languages (cf. Dryer 2014: e239).

$38 \quad$ Number of occurrences in the categories $\S 2.5$ to $§ 2.8$. 
The percentage of the indefinite article in British and American English ${ }^{39}$ is about seven times higher than in Iraqi and Khuzestani Arabic. ${ }^{40}$ This disparity in use is also illustrated well by a small-scale comparison of Arabic texts from Baghdad and Khuzestan with their English translations: in the English translations, the indefinite article is more than seven times more common than in the Arabic texts. The number of the definite articles, however, is almost the same, just slightly higher in the Arabic than in English. Hence, despite the relatively small sample, ${ }^{41}$ it is clear that the scope of the definite articles is roughly equivalent in Iraqi/Khuzestani Arabic and English, whereas the role of the indefinite articles is significantly different.

\section{5 /fard/and the co-referential dative}

A tendency found in both Iraqi and Khuzestani Arabic is the correlation of /fard/ and a dative pronoun that is co-referential with the subject of the clause. Such co-referential datives (also called "ethical datives") are, like /fard/, predominantly bound to an indefinite object (Haddad 2018: 173; Al-Zahre and Boneh 2010: 260) and described as markers of intersubjectivity-i.e., they mark the speakers' awareness of their "own feelings, expectations, attitudes, and beliefs, as well as their familiarity with their hearers' expectations, attitudes, and beliefs" (Haddad 2018: 166). A similar scenario to the frequent cooccurrence of Iraqi and Khuzestani Arabic co-referential datives with /fard/ is found in Syrian Arabic, where co-referential datives cannot appear with bare indefinite direct objects, but must "feature some expression of attenuative vague measure"-e.g., the adverb šwayy 'a little', the quantifiers kam 'several' and š 'some' (Al-Zahre and Boneh 2010: 256, 258-261; 2016:5), or the indefinite pronoun wāhad 'one, someone' (Al-Zahre and Boneh 2010: 261-262). Particularly when epistemic specificity is expressed (see $§ 2.7$ ), the existence of a co-referential dative pronoun is a prerequisite for speakers to mark a noun with /fard/, as in (59), which may be uttered in a library.42

39 Cf. https://www.english-corpora.org/bnc/ and https://www.english-corpora.org/coca/. Many thanks to our colleague Barbara Seidlhofer (University of Vienna) for helping us with the English corpora.

40 The difference is slightly lower in the al-Hilla corpus, which is, however, very small. The Kwayriš corpus stands out because of its genre (see below).

41 Sample: $\mathrm{n}=17,500$ words. $/$ fard $/=60 ;$ English $/ \mathrm{a} /$ and $/$ some $/=444$. Definite articles: Arabic /il- / = 1,676; English /the/ = 1,342. The sample was taken from both narrative and conversational sections of the McCarthy and Raffouly (1965) corpus (Baghdad) and the corpus Leitner (Khuzestan).

42 Other examples include (28), (30) and (31) above. 
(59) Khuzestan (elicited)

a. a-dawwar-l-i 'sala farad qāmūs

1SG-seek-for-1SG for INDEF dictionary

'I am looking for a dictionary.' (Yesterday it was still here.)

b. a-dawwar 'ala ("farad) qāmūs

1SG-seek for dictionary

'I am looking for a dictionary.' (And not a grammar book.)

Example (6o) from Syrian Arabic contains a co-referential dative and the indefinite marker ši:

(6o) Syrian Arabic (Lentin 2003: 112)

iza badd-ak b-wașș-l-ak

Sa-l-balad

if want-2MSG IND-accompany-for-2MSG to-DEF-city

bə-t-šaf-l-ak ši makanisyān

IND-2-see-for-2MSG INDEF mechanic

'Si tu veux, je te raccompagne en ville, tu te chercheras un garagiste.' [If you'd like, I will go with you to the city and find you a mechanic.]

In combination with with a co-referential dative, /fard/ also expresses ausually positive — attitude toward the object marked by it—i.e., /fard/ signals connotative usage, sometimes additionally specified by an adjectival attribute as in (61), in which the speaker talks about a trip that he could not make this year, but hopefully can next year.

(61) Baghdad (McCarthy and Raffouly 1965:50)

$w$-a-sawwi-l-i fas-safra żayyra.

and-1SG-make-for-1SG INDEF-trip small

'And I take a little trip for myself.'

Like the strikingly similar usage of diminutives (Dressler and Merlini Barbaresi 1994: 136-137), connotations with regard to drinks are without exception positive. In (62), two friends are talking about having something to drink together before they go to the cinema.

(62) Baghdad (McCarthy and Raffouly 1965:9) xall-in-rūḥ il bèt-na w-ni-šrab-in-na fadd finğān gahwa let-1PL-go to house-1PL and-1PL-drink-for-1PL INDEF cup coffee 


\section{lō fadd istikān čāy. \\ or INDEF glass tea}

'Let's go to our house and have ourselves a cup of coffee or a glass of tea!'

It is beyond the scope of this article to identify potential cognitive connections between the use of these two optional pragmatic devices, but it appears that there is a significant correlation in their contexts of use.

\section{Summary}

In the light of the above discussion of the polyfunctional item /fard/, we can state that the details of its use are very complex indeed. This is not entirely surprising, as Matthew Dryer states that, "[f]or many languages, one can only get a rather vague idea of what governs the use of articles" (2014: e241). Our article can only be a first attempt to systematically explore the mechanisms and processes behind the complex use of /fard/ in Iraqi and Khuzestani Arabic based on speech data of various published text corpora and additional data elicited from speakers of these two varieties.

As far as its attested semantic functions are concerned, the Iraqi and Khuzestani Arabic /fard/ is a fully developed indefinite article. On a syntactic level, however, its use is not nearly as systematized and is thus much less frequent than, for instance, that of the English indefinite article. This is also because its use is in most cases optional.

In section 2, we presented the main functions of the indefinite article /fard/ along a proposed grammaticalization path for this item. Based on our findings and the statistics of our data, we propose that, from a diachronic perspective, the noun /fard/ first became a quantifier that marks singularity. From this stage it developed in different directions: an intensifier, the scalar adverb "only," a marker of approximation and a presentative marker. From this stage, it further came to be used as an individuation and free-choice marker, and finally a mitigating device used in imperatives and polite requests.

Section 3 discusses restrictions and limiting contexts, particularly its use in combination with mass and plural nouns and with parts of speech other than nouns. Section 4 contains a quantitative analysis of the occurrences of /fard/ in our data, a summary of the proposed grammaticalization path of /fard/ and the processes behind its various grammaticalization stages, an argumentative discussion of why it can be labelled an indefinite article, and, finally, some remarks on its frequent co-occurrence with co-referential datives. 
Although our findings are based on the analysis of more than 5 oo occurrences, we are aware that we could not explore all of the complex details of the use of /fard/. We see this article as a first step toward a better understanding of this form that will hopefully encourage further research on this topic. Such future research is ideally based on a larger corpus that includes both narratives as well as dialogues of everyday speech. Especially helpful for a better understanding of some of the functions of /fard/ would be an in-depth prosodic analysis, the realization of which was limited for this article, as the greater part of our corpora was available only in written form.

\section{Abbreviations}

$\begin{array}{llll}\text { ADJ } & \text { adjective } & \text { M } & \text { masculine } \\ \text { AP } & \text { active participle } & \text { NEG } & \text { negation } \\ \text { DEF } & \text { definite article } & \text { NP } & \text { noun phrase } \\ \text { DEM } & \text { demonstrative } & \text { NUM } & \text { numeral } \\ \text { DIM } & \text { diminutive } & \text { PL } & \text { plural } \\ \text { DUAL } & \text { dual } & \text { PN } & \text { proper name } \\ \text { F } & \text { feminine } & \text { PROG } & \text { progressive } \\ \text { FUT } & \text { future } & \text { REL } & \text { relative pronoun } \\ \text { IMP } & \text { imperative } & \text { SG } & \text { singular } \\ \text { IND } & \text { indicative } & \text { VOC } & \text { vocative particle } \\ \text { INDEF } & \text { indefinite } & & \end{array}$

\section{References}

Al-Karmalī, Anastās Mārī. 2oog. Mazārāt Bag̉dād. London: Al-Warrak Publishing. Aloni, Maria, and Angelika Port. 2015. "Epistemic Indefinites and Methods of Identification." In Epistemic Indefinites: Exploring Modality Beyond the Verbal Domain, edited by L. Alonso-Ovalle and P. Menéndez-Benito, 117-140. Oxford: Oxford University Press.

Alonso-Ovalle, Luis, and Paula Menéndez-Benito. 2013. "Two Views on Epistemic Indefinites." Language and Linguistics Compass 7 (2): 105-122.

Al-Zahre, Nisrine, and Nora Boneh. 2010. "Coreferential Dative Constructions in Syrian Arabic and Modern Hebrew." Brill's Journal of Afroasiatic Languages and Linguistics 2 (1): 248-282.

Al-Zahre, Nisrine, and Nora Boneh. 2016. "Pronominal Non-Core Datives in Syrian Arabic." Brill's Journal of Afroasiatic Languages and Linguistics 8 (1): 3-36. 
Archer, Dawn. 2017. "Politeness." In The Routledge Handbook of Pragmatics, edited by Anne Barron, Yueguo Gu, and Gerard Steen, 384-398. London \& New York: Routledge.

Belaj, Branimir, and Darko Matovac. 2015. "On the Article-like Use of the Indefinite Determiners Jedan and Neki in Croatian and Other Slavic Languages." Suvremena Lingvistika 41 (79): 1-20.

Blanc, Haim. 1964. Communal Dialects in Baghdad. Cambridge, Mass.: Center for Middle Eastern Studies of Harvard University.

Breban, Tine. 2015. "Refining Secondary Grammaticalization by Looking at Subprocesses of Change." Language Sciences 47 (B):161-171.

Brown, Penelope, and Stephan Levinson. 1987. Politeness: Some Universals in Language Usage. Cambridge: Cambridge University Press.

Brustad, Kristen. 200o. The Syntax of Spoken Arabic: A Comparative Study of Moroccan, Egyptian, Syrian, and Kuwaiti Dialects. Washington: Georgetown University Press.

De Mulder, Walter, and Anne Carlier. 2011. "The Grammaticalization of Definite Articles." In The Oxford Handbook of Grammaticalization, edited by Heiko Narrog and Bernd Heine, 519-531. Oxford: Oxford University Press.

Denz, Adolf, and Otto Edzard. 1966. "Iraq-arabische Texte nach Tonbandaufnahmen aus al-Hilla, al-'Afač und al-Bașra.” Zeitschrift der Deutschen Morgenländischen Gesellschaft 116: 6o-96.

Dressler, Wolfgang U., and Lavinia Merlini Barbaresi. 1994. Morphopragmatics: Diminutives and Intensifiers in Italian, German, and Other Languages. Berlin \& New York: De Gruyter.

Edzard, Lutz. 2006. “Article, Indefinite." In Encyclopaedia of Arabic Language and Linguistics, edited by Kees Versteegh, 1: 188-191. Leiden: Brill.

Erwin, Wallace M. 1963. A Short Reference Grammar of Iraqi Arabic. Washington D.C.: Georgetown University Press.

Esseesy, Mohssen. 2018. "Typological Features of Grammaticalization in Semitic." In Grammaticalization from a Typological Perspective, edited by Heiko Narrog and Bernd Heine, 35-56. Oxford: Oxford University Press.

Haddad, Youssef A. 2018. "The Pragmatics-Syntax Division of Labor. The Case of Personal Datives in Lebanese Arabic." In The Routledge Handbook of Arabic Linguistics, edited by Elabbas Benmamoun and Reem Bassiouney, 155-179. Routledge Handbooks. London \& New York: Routledge, Taylor \& Francis Group.

Hanitsch, Melanie. 2019. Verbalmodifikatoren in den arabischen Dialekten:Untersuchungen zur Evolution von Aspektsystemen. Porta Linguarum Orientalium 27. Wiesbaden: Harrassowitz.

Haspelmath, Martin. 1997. Indefinite Pronouns. Oxford Studies in Typology and Linguistic Theory. Oxford: Clarendon Press. 
Heine, Bernd. 1997. Cognitive Foundations of Grammar. New York: Oxford University Press.

Heine, Bernd, and Tanja Kuteva. 2007. The Genesis of Grammar: A Reconstruction. Oxford: Oxford University Press.

Holes, Clive. 2007. “Colloquial Iraqi Arabic.” In Languages of Iraq, Ancient and Modern, edited by J.N. Postgate, 123-134. Bagdad: British School of Archaeology in Iraq.

Hopper, Paul J. 1991. “On Some Principles of Grammaticization.” In Approaches to Grammaticalization. I: Focus on Theoretical and Methodological Issues, edited by Elizabeth Closs Traugott and Bernd Heine, 17-35. Amsterdam \& Philadelphia: John Benjamins.

Hopper, Paul J., and Elizabeth C. Traugott. 2003. Grammaticalization. 2nd ed. Cambridge: Cambridge University Press.

Ingham, Bruce. 2007. "Khuzestan Arabic." In Encyclopedia of Arabic Language and Linguistics, 2:571-578. Leiden: Brill.

Jastrow, Otto. 1979. "Zur Arabischen Mundart von Mossul." Zeitschrift Für Arabische Linguistik 2: 36-76.

Jastrow, Otto. 1991. "Brotbacken: Ein Text Im arabischen Dialekt der Juden von Mossul in Memoriam Ezra Laniado." Zeitschrift Für Arabische Linguistik 23: 7-13.

Jastrow, Otto. 2004. "Jüdisches, christliches und muslimisches Arabisch in Mossul." In Approaches to Arabic Dialects: A Collection of Articles Presented to Manfred Woidich on the Occasion of His Sixtieth Birthday, edited by Martine Haak, Rudolf De Jong, and Kees Versteegh, 135-15o. Leiden: Brill.

Jastrow, Otto. 2005. "Linsen mit Reis—Und doch keine Mžaddara! Jüdisch-arabische Kochrezepte aus Mossul." In Alltagsleben und materielle Kultur in der arabischen Sprache und Literatur: Festschrift für Heinz Grotzfeld zum 70. Geburtstag, edited by Thomas Bauer, 223-232. Wiesbaden: Harrassowitz.

Jastrow, Otto. 2007. "Iraq." In Encyclopaedia of Arabic Language and Linguistics, 2: 414424. Leiden: Brill.

Khan, Geoffrey. 1999. A Grammar of Neo-Aramaic: The Dialect of the Jews of Arbel. Handbook of Oriental Studies. First Section, The Near and Middle East, 47. Bd. Leiden: Brill.

Kranich, Svenja. 2008. "Subjective Progressives in Seventeenth and Eighteenth Century English. Secondary Grammaticalization as a Process of Objectification.” In English Historical Linguistics 2006: Selected Papers from the Fourteenth International Conference on English Historical Linguistics (ICEHL 14), Bergamo, 21-25 August 2006. Volume I: Syntax and Morphology, edited by Maurizio Gotti, Marina Dossena, and Richard Dury, 241-256. Amsterdam: Benjamins.

Kuteva, Tania, Bernd Heine, Bo Hong, Haiping Long, Heiko Narrog, and Seongha Rhee, eds. 2019. World Lexicon of Grammaticalization. Cambridge: Cambridge University Press. 
Lane, Edward William. 1863. An Arabic-English Lexicon Derived from the Best and Most Copious Eastern Sources. London: Williams and Norgate.

Leitner, Bettina. 2020. "The Arabic Dialect of Khuzestan (Southwest Iran): Phonology, Morphology and Texts." PhD Thesis. Vienna: University of Vienna.

Leitner, Bettina, Erik Anonby, Dina El-Zarka, and Mortaza Taheri-Ardali. 2021. "A First Description of Arabic on the South Coast of Iran: The Arabic Dialect of Bandar Moqām, Hormozgan." Journal of Semitic Studies 66 (1).

Leitner, Bettina, Fady German, and Stephan Procházka. 2021. Lehrbuch des IrakischArabischen: Praxisnaher Einstieg in den Dialekt von Bagdad. Wiesbaden: Harrassowitz.

Lentin, Jérôme. 2003. "Datif éthique, datif coréférentiel et voix moyenne dans les dialectes arabes du Bilâd al-Shâm et quelques problémes connexes." Edited by Ayoub Georgine and Jérôme Lentin. Cahiers de Linguistique de l'INALCO 5: 99-130.

Levin, Aryeh. 1975. "The Vernacular Poetry of Safiyy Al-Dīn al-Hillī, a Source for the Reconstruction of Iraqi Arabic in the 14th Century." Israel Oriental Studies 5: 259276.

López-Couso, María, and Elena Seoane. 2017. "Grammaticalization." In The Routledge Handbook of Pragmatics, edited by Anne Barron, Yueguo Gu, and Gerard Steen, 277292. London \& New York: Routledge.

Malaika, Nisar. 1963. Grundzüge der Grammatik des arabischen Dialektes von Bagdad. Wiesbaden: Harrassowitz.

Masliyah, Sadok. 1999. "Oaths in Spoken Iraqi Arabic." Journal of Semitic Studies 44 (i): 83-103.

McCarthy, R.J., and Faraj Raffouli. 1965. Spoken Arabic of Baghdad. Part 2: Anthology of Texts. Beirut: Librairie Orientale.

Meißner, Bruno. 1903. "Neuarabische Geschichten aus dem Iraq." Beiträge zur Assyrologie und semitschen Sprachwissenschaft 5 (1): 203.

Mion, Giuliano. 2009. "L' indetermination nominale dans les dialectes arabes. Une vue d' ensemble." In Miscellanea arabica 2009, edited by Angelo Arioli, 215-231. Rome: Sapienza Università, Facoltà di Studi Orientali.

Narrog, Heiko, and Bernd Heine, eds. 2018. Grammaticalization from a Typological Perspective. Oxford: Oxford University Press.

Pat-El, Na'ama. 2009. "The Development of the Definite Article in Semitic: A Syntactic Approach." Journal of Semitic Studies 54 (1): 19-50.

Presslich, Marion. 2000. Partitivität und Indefinitheit: Die Entstehung und Entwicklung des indefiniten Artikels in den germanischen und romanischen Sprachen am Beispiel des Deutschen, Niederländischen, Französischen und Italienischen. Frankfurt am Main: Peter Lang.

Procházka, Stephan. 2019. "The Diminutive in the Arabic Dialect of Tunis." In Studies on Arabic Dialectology and Sociolinguistics: Proceedings of the 12th International 
Conference of AIDA Held in Marseille from May 3oth to June 2nd 2017, edited by Catherine Miller, Alexandrine Barontini, Marie-Aimée Germanos, Jairo Guerrero, and Christophe Pereira. Livres de l'IREMAM. Aix-en-Provence: IREMAM. http:// books.openedition.org/iremam/3878.

Rubin, Aaron D. 2005. Studies in Semitic Grammaticalization. Winona Lake, Indiana: Eisenbrauns.

Schroeder, Christoph. 1999. The Turkish Nominal Phrase in Spoken Discourse. Turcologica, Bd. 40. Wiesbaden: Harrassowitz.

Seeger, Ulrich. 2002. "Zwei Texte im Dialekt der Araber von Chorasan." In "Sprich doch mit deinen Knechten Aramäisch, wir verstehen es!" 6o Beiträge zur Semitistik. Festschrift für Otto Jastrow zum 6o. Geburtstag, edited by Werner Arnold and Hartmut Bobzin, 629-646. Wiesbaden: Harrassowitz.

Seeger, Ulrich. 2013. "Zum Verhältnis der zentralasiatischen arabischen Dialekte." In Nicht nur mit Engelszungen. Beiträge zur Semitischen Dialektologie: Festschrift für Werner Arnold zum 6o. Geburtstag, edited by Renaud Kuty, Ulrich Seeger, and Shabo Talay, 313-322. Wiesbaden: Harrasowitz.

Testen, David D. 1998. Parallels in Semitic Linguistics: The Development of Arabic La-and Related Semitic Particles. Leiden: Brill.

Traugott, Elizabeth Closs. 2003. "From Subjectification to Intersubjectification." In Motives for Language Change, edited by R. Hickey, 124-139. Cambridge: Cambridge University Press.

Traugott, Elizabeth Closs. 2012. "Pragmatics and Language Change." In The Cambridge Handbook of Pragmatics, edited by Keith Allan and K.M. Jaszczolt, 549-565. Cambridge: Cambridge University Press.

Waltereit, Richard. 2012. "On the Origins of Grammaticalization and Other Types of Language Change in Discourse Strategies." In Grammaticalization and Language Change: New Reflections, edited by Kristin Davidse, Tine Breban, Lieselotte Brems, and Tanja Mortelmans, 51-72. Amsterdam: Benjamins.

Waltisberg, Michael. 2016. Syntax des Țuroyo. Semitica Viva, Band 55. Wiesbaden: Harrassowitz Verlag.

Weiss, Daniel. 2004. "The Rise of an Indefinite Article: The Case of Macedonian Eden." In What Makes Grammaticalization? A Look from Its Fringes and Its Components, edited by Walter Bisang, Nikolaus Himmelmann, and Björn Wiemer, 139-165. Trends in Linguistics 158. Berlin/Boston: Mouton de Gruyter.

Woidich, Manfred. 2006. Das Kairenisch-Arabische: Eine Grammatik. Porta Linguarum Orientalium, N.S. 22. Wiesbaden: Harrassowitz. 